\title{
Receptor tyrosine kinases in human platelets: A review of expression, function and inhibition in relation to the risk of bleeding or thrombocytopenia from phase I through phase III trials
}

\begin{abstract}
Tyrosine kinases (TKs) are divided into two main categories: receptor tyrosine kinases (RTK) and non-receptor tyrosine kinases (NRTK). RTKs include approximately 21 families. Examples of RTKs are epidermal growth factor receptor (EGFR), platelet-derived growth factor receptor (PDGFR), and fibroblast growth factor receptor (FGFR). Tyrosine Kinase Inhibitors (TKIs) are used to treat both hematologic and solid malignancies. They have variable side effects, one of which is a platelet type bleeding diathesis.

Platelets are the cornerstone of primary hemostasis. They exert this function through different steps and mechanisms mediated by surface receptors and downstream messengers, which, in part, are Tyrosine Kinases. TKs create conformational changes that help form a solid fibrin rich plug or thrombus.

In this review we will shed the light on potential mechanisms by which TKIs lead to a higher bleeding risk. We identify the receptors needed for interaction between the platelets and vWF, collagen, fibrinogen, and others. We then dissect the effect of TKIs according to the signaling pathway involved and elaborate on the bleeding and thrombocytopenic risk with the use of Insulin Growth Factor, Epidermal Growth Factor and Vascular Growth Factor inhibitors.
\end{abstract}

Volume 8 Issue 6 - 2017

\author{
Houssein Abdul Sater, Arpita Shah Gandhi, \\ Paul Dainer, Jeremy Pantin \\ Augusta University, Georgia Cancer Center, USA
}

Correspondence: Marcio Luis Duarte, WEBIMAGEM, Avenida Marques de Sao Vicente 446, Sao Paulo, Sao Paulo, Brazil,,Te 55xx 1398 I | 12799, Email houssein.md@gmail.com

Received: May 18, 2017 | Published: November 07, 2017

\section{Introduction}

\section{Tyrosine kinases}

Tyrosine kinases (TK) are enzymes that play role in many cell functions, including cell signaling, growth, and division. ${ }^{1}$ They may be activated or found at high levels in different cancer cells. Thus blocking their function may serves as a means to block cancer cells from proliferating. The best way to understand their role in cell machinery is view them as on and off switches for a variety of enzymatic activities. These domino-like effects are translated eventually into immediate conformational changes, or proliferation and apoptosis via transcription, translation, and post translational modifications. Based on their cellular location they are divided in two categories: transmembranous receptor (RTK) or intracellular (NRTK). ${ }^{2}$ Both catalyze ATP and add a phosphate residue to other amino acids or peptides resulting in conformational changes affecting their target's function, which could be the TK itself (auto phosphorylation). ${ }^{3}$

TK are further divided into families based on their function and

Table I Receptor Tyrosine Kinase Families and their members structure. We differentiate transmemebranous RTKs into about 21 families listed in Table 1. Non-receptor tyrosine kinases (NRTKs) include approximately 10 groups or families based on their structure and all share the Src-Homology 2 domain or SH-2. These are discussed in another review to be published separately.

RTKs normally rest in the OFF mode until a trigger activates them. RTK span the cell membrane with 3 domains: an extracellular receptor domain, a membranous anchoring domain and an intracellular kinase domain. Ligand binding normally induces activation via structural changes in one or different neighbor receptors. The resulting alterations may lead to proximity of membranous parts, and thus open inactive domains and turn them on to an active mode, again the "switch analogy". The resulting process of approximating two receptor structures together is called dimerization, and there is a spectrum of mechanisms that make this occur. ${ }^{3}$. Two identical receptors (a dual receptor) or two similar receptors located in close proximity on the membrane are brought together. Other methods of combing the different receptor structures together in which the ligand, receptors, and other molecules may be involved have been described as well. ${ }^{4}$

\begin{tabular}{lll} 
ErbB (EGFR, ERB2,3,4) & Ror( Ror I,2) & Ryk \\
\hline Ins (InsR, IGFIR, InsRR) & MuSK & DDR(DDRI,2) \\
PGDF(PDF $\alpha$, PDGF $\beta$, CSFIR/Fms, Kit/SCFR, FLT3/FIK2) & Met( Met, Ron) & Ros \\
VEGF(VEGFRI/FItI,VEGFR2/KDR,VEGFR3/FIt4) & AXL(AxI, Mer,Tyro3) & LMR(LMRI-3) \\
FGF(FGFRI-4) & Tie (TieI, 2) & ALK(ALK, LTK) \\
PTK7(PTK7/CCK4) & Eph(EphAI-10, EphBI-6) & STKYI(STKYI, SuRTKI06) \\
Trk(TrkA-C) & Ret & Mck(MCKI0,TYROI0) \\
\hline
\end{tabular}


Cellular tyrosine kinase phosphorylation is normally regulated by the antagonizing interaction between tyrosine kinases and tyrosine phosphatases. ${ }^{5}$ The normal mechanism by which receptor and nonreceptor tyrosine kinases are activated is highly dependent on the location and structure which is usually altered in disease states. Genetic mutations and chromosomal alterations are the most commonly known mechanisms driving these kinases into the abnormally "ON" position without the need of other drivers that normally lead to their activation as ligands in case of RTKs. Common examples of TK activated by mutations leading to malignancies include EGFR, PDGF, VEGF, JAK and BTK.

\section{Tyrosine kinase inhibitors}

Tyrosine kinase inhibitors (TKIs) are primarily administered orally, and their utilization for the treatment of both solid tumors and hematological malignancies has demonstrated significant growth over the last two decades. ${ }^{6}$ Each drug is a small molecule engineered to target a specific TK in critical domains that would halt its function. Targets include the ligand binding, receptor binding, and dimerization or kinase sites. Due to the similarity in structure of TKs, a single TKI may block a single or several kinases based on its affinity and concentration. Out of these observations arises the non-clean molecular concept, which also implies cross resistance to familybased TK inhibition and potential variations in side effect profiles.?

There has been numerous approvals of TKIs by US Food and Drug Administration since the discovery of imatinib, the BCRABL inhibitor which changed the natural history of chronic myeloid leukemia. ${ }^{8}$. Approximately 24 drugs have already been approved; however, many more are undergoing continual investigation. This survey will address each family of TKIs and review evidence from Phase I through Phase III studies on the risk of bleeding or platelet dysfunction with each drug. We will then focus upon approved drugs particularly those with anti EGFR, and anti VEGFR activity.

\section{Platelet function and physiology}

Platelets constitute an essential player in normal primary hemostasis. They are anucleate cellular fragments with membranes covered by unique receptors. Internally, platelets have a cytoplasm shaped by a cytoskeleton, a dense tubular system, mitochondria, glycogen granules, peroxizomes, dense granules and alfa granules. Platelets provide the backbone or scaffold needed to achieve appropriate thrombosis and halt bleeding at the sites of injury or breeches of blood vessels. Platelets are recruited to the field of traumatized tissue where they are activated by exposed sub endothelial collagen, coated with von Willebrand Factor (vWF), particularly in areas of high shear stress as arteries, to achieve primary hemostasis. The first phase in this process is termed initiation or tethering, where platelets interact through their surface receptors, glycoproteins $\mathrm{Ib}$ (GP Ib) and VI (GP VI)) and integrin $\boldsymbol{\alpha} 2 \boldsymbol{\beta} 1$ with vWF and fibrillary collagen respectively. During this phase, platelets coat the site of injury and trigger downstream signals to enhance adhesion, activation, and recruitment of additional platelets. The second phase is called extension phase where platelets change their conformational and secrete several soluble agonists from their granules. These include ADP, thrombin, and thromboxane A2 (TxA2), which work by autocrine or paracrine effects to activate themselves and neighboring platelets. The interaction of these agents with their $G$ protein-coupled receptors generate an inside outside signal through conformational changes, but equally important, through increased activation of certain integrins, particularly $\boldsymbol{\alpha} 2 \boldsymbol{\beta} 3$, which binds to fibrinogen at higher

affinity once activated compared to its resting state. The binding of integrin $\boldsymbol{\alpha} 2 \boldsymbol{\beta} 3$ to fibrinogen leads to further platelet aggregation and clot retraction. The final phase, which consolidates the clot or plug formation, is called the stabilization phase. In this phase the aggregate is made stable long enough to prevent premature clot dissolution or disaggregation. All three steps are seen currently as a continuum of events, and the thrombus is conceptualized as a dynamic event, characterized by continuous signaling.

\section{Platelet tyrosine kinase signaling}

There are different receptor types involved in platelet signaling, some of which are RTKs (Table 2). They all use a direct or indirect tyrosine kinase pathway for downstream signaling. ${ }^{9}$ The contribution of each of receptor and its signal in thrombus formation or its bleeding risk, when absent, is under active study. ${ }^{10}$

Table 2 Different Receptors expressed on human platelets with their ligands

\begin{tabular}{ll}
\hline Platelet receptor family & Different members of the family \\
\hline Integrins & Adrenaline Receptor: $2 \mathrm{I}(\mathrm{GPla} / \mathrm{lla})$ \\
& Fibrinogen Receptor: $23(\alpha \mathrm{llb} \beta 3)$ \\
& Others: $5 \mathrm{I}, 6 \mathrm{I}$, and $\mathrm{v} 3$.
\end{tabular}

Leucine-Rich Repeated

Receptors

G protein coupled Receptors

Immunoglobulin Ig Superfamily related

C-type lectin Receptors

Tyrosine Kinase Receptors

Miscellaneous

Based on an extensive literature review, we present in the following paragraphs the different receptor tyrosine kinases proven by evidence to play roles in platelet physiology and or pathology. We will dissect their role and downstream effectors and potential effects once inhibited.

\section{Receptor tyrosine kinase families in platelets}

Tyrosine kinase receptors present on the surface of human platelets include thrombopoietin receptor or c-MPL, Gas-6 receptors, ephrins and IGF-1 receptor (Table 2).

\section{Insulin (Ins) family}

Insulin-like growth factor-1 (IGF-1) receptor expressed on the platelet surface is a member of Insulin (Ins) family. IGF-1 exists in $\alpha$ granules of platelets and stimulates tyrosine phosphorylation of insulin receptor substrates 1 (IRS-1) and 2 (IRS-2). These become associated with the $\mathrm{p} 85$ subunit of phosphoinositide-3 kinase (PI3K) temporarily and lead to protein kinase $\mathrm{B}$ ( $\mathrm{PKB}$ ) phosphorylation also 
known as AKT. Thrombin mediated platelet aggregation via PAR1 is potentiated by IGF-1 and this is reversed by PI $3 \mathrm{~K} \alpha$ inhibitors. The contribution of PI3K p110 $\alpha$ for activation of AKT demonstrates that IGF-1 potentiates platelet aggregation by complementing the Gi (linked to PI3K $\beta$ ) but not the Gq-signaling pathways. ${ }^{11-13}$ Although IGF-1 is not considered a major player in platelet function, data from several phase I and phase II studies of IGF1R inhibitors have shown their presence is associated with some evidence of bleeding (GI) and thrombocytopenia. ${ }^{14}$ In Table 3 we cite several phase I-III studies of small molecule inhibitors or antibodies targeting IGF-1 Receptor. While the monoclonal antibody AMG 479 has caused significant thrombocytopenia, there have been no reports of bleeding. Most other tyrosine kinase inhibitors reviewed have had no effect on platelets reported. It is also noted that many of these trials were terminated by sponsors for reasons, such as shortfalls of accrual. On the other hand, PI $3 \mathrm{~K} \alpha$ selective inhibitors remain under study with no data yet available on their adverse event profile.

Table 3 Insulin-like growth factor-I (IGF-I) receptor Inhibitors

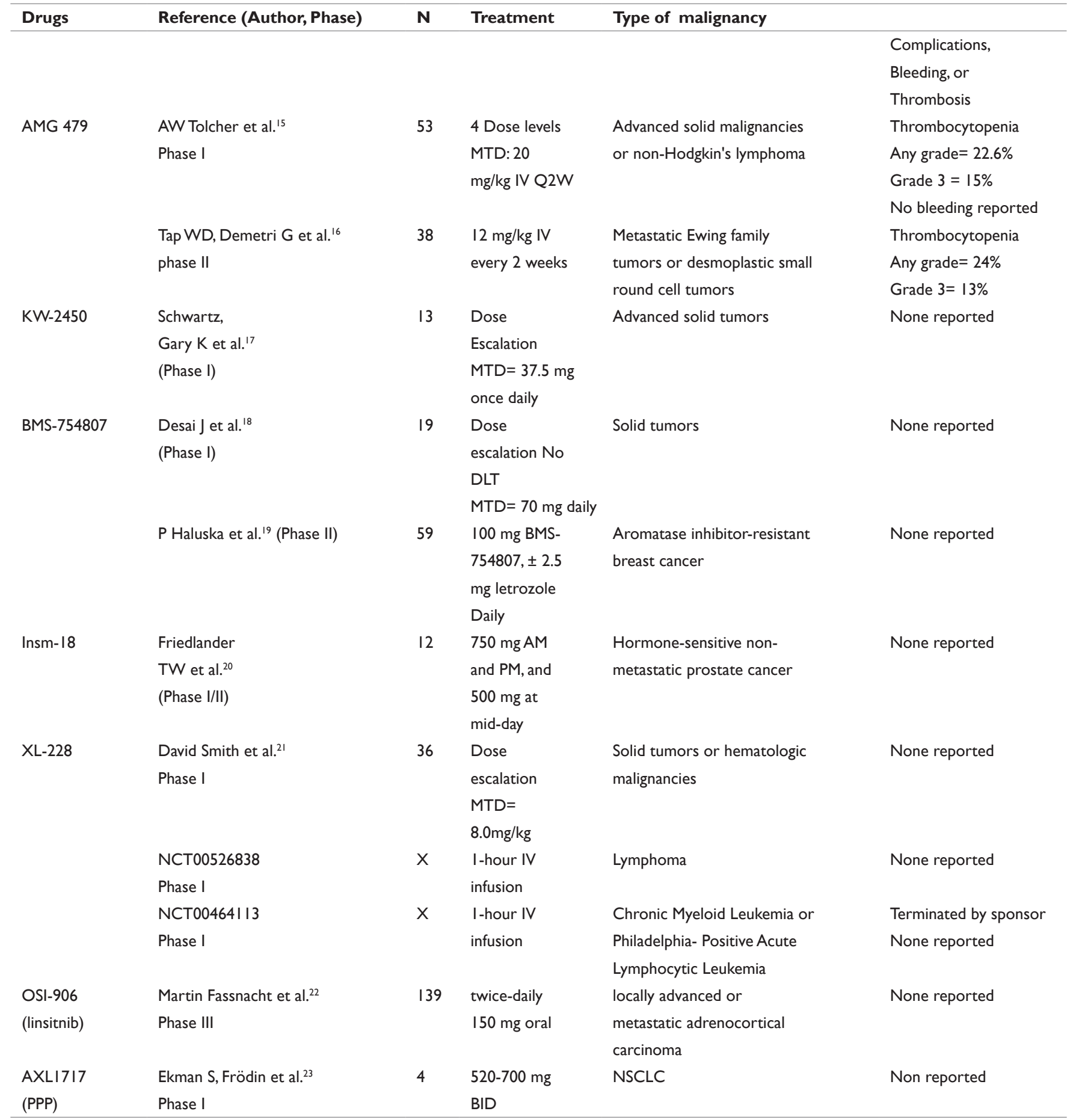




\section{Thrombopoietin receptor}

Thrombopoietin (TPO) receptor, c-Mpl, is expressed on megakaryocyte progenitors, mature megakaryocytes, and platelets. It has been observed in various studies of human platelets that TPO results in tyrosine phosphorylation of several proteins including the c-Mpl receptor, the $85-\mathrm{kD}$ subunit of PI3K, Janus kinase 2 (Jak2) and Shc. ${ }^{24,25}$ TPO induced tyrosine phosphorylation is time and dosedependent and reaches a maximum in about 5 minutes. Both Jak2 and Shc are tyrosine phosphorylated shortly after stimulation. Jak2 phosphorylation is accompanied by increased kinase activity, whereas Shc tyrosine phosphorylation is associated with Grb2. Although PI3K phosphorylation is independent of extracellular fibrinogen and ligation of integrin $\boldsymbol{\alpha} 2 \boldsymbol{\beta} 3$ ( $\alpha \mathrm{IIb} \beta 3$ ), TPO induces concentration dependent platelet aggregation in presence of fibrinogen and immobilized collagen. Aggregation with fibrinogen is blocked by the soluble c-Mpl receptor. This phenomenon suggests that PI3K, Jak2, Shc, and Grb2 are involved in signal transduction after ligand binding to c-mpl in human platelets. ${ }^{24}$ TPO thus participates in direct platelet activation and modulates platelet-extracellular matrix interactions. ${ }^{25}$ There is no known proven therapeutic benefit in c-mpl inhibition but it might serve as a potential target in myeloproliferative diseases, such as essential thrombocytosis.

\section{TAM family}

Gas6 is a vitamin K-dependent protein that is expressed in and released by many cell types with variable functions, such as reversible growth arrest, survival, proliferation, and inflammation. Gas6 (encoded by growth arrest-specific gene 6) is an extracellular ligand for receptor tyrosine kinases of the TAM family, namely Tyro3, Axl, and Mer. PI3K is an important downstream effector of TAM family. ${ }^{7,9}$ Interaction of murine and human Gas 6 with the platelet TAM receptors plays an important role in arterial thrombus formation. Human Gas6 enhances and prolongs the phosphorylation of AKT through PI3K, and this activity synergizes with ADP-P2Y12 signaling as it stimulates tyrosine phosphorylation of the $\beta 3$ integrin. ADP-induced platelet aggregation is impaired by removal of Gas6 from plasma, a condition provoking gradual platelet disaggregation and integrin $\alpha \operatorname{Ilb} \beta 3$ inactivation if subject to blood flow. Recombinant human Gas6 reverses the effects of Gas6 removal, and in a mouse model, it was completely antagonized by external ADP. In conclusion ADP-P2Y12 and Gas6-TAM activation pathways synergize to achieve persistent $\alpha \operatorname{IIb} \beta 3$ activation and platelet aggregation. ${ }^{79}$ Blocking the Gas6-R- $\alpha$ IIb $\beta 3$ integrin cross-talk might be a novel approach to the reduction of thrombosis. ${ }^{26}$

\section{Ephrins (Eph)}

Human platelets express on their surface the Ephrin (Eph) RTKs, EphA4 and EphB1. These RTKs are normally activated by their corresponding eprhins. While A ephrins only bind to EphA, EphA4 can associate with B ephrins. Prevost et al. ${ }^{27,28}$ demonstrated that EphA4 is physically associated with $\alpha \mathrm{IIb} \beta 3$ in resting platelets, increases its surface expression when platelets are activated, and co-localizes with $\alpha \operatorname{IIb} \beta 3$ at sites of contact between platelets. They also showed that Eph/ephrin interactions can help stabilize aggregation of platelets on collagen under flow and contribute to "outside-in" signaling through $\alpha \operatorname{IIb} \beta 3$ by facilitating tyrosine phosphorylation of the $\beta 3$ cytoplasmic domain, which allows myosin to bind to $\alpha \operatorname{IIb} \beta 3$ and clot retraction to occur. EphA4 ephrin and its receptors can accomplish this by bringing kinases into complexes that include the integrin and the two Src family members, Fyn and Lyn, during platelet activation. Association of ephrinB1 and its receptors favors continued growth and stability of the thrombus by a similar mechanism. ${ }^{27}$ Eph-ephrin interactions enhance platelet adhesion to soluble or immobilized fibrinogen, whereas its inhibition weakens platelet aggregation. Understanding these processes may provide additional targets for reducing thrombosis and may have potential for use in acute settings. ${ }^{29}$ Limited data implicate some ephrins as pro-thrombotic factors. ${ }^{30,31}$

\section{Immunoreceptor tyrosine-based activation motif (ITAM) - GPVI}

The glycoprotein VI (GPVI)-FcR $\gamma$-chain complex initiates a powerful activation of platelets by exposed collagen and laminin through an immunoreceptor tyrosine-based activation motif (ITAM)regulated signaling pathway. ITAMs are characterized by two YxxL sequences separated by 6-12 amino acids and are found associated with several classes of immunoglobulin (Ig) and C-type lectin receptors in hematopoietic cells, including $\mathrm{Fc}$ receptors. Cross-linking of the Ig GPVI leads to phosphorylation of two conserved tyrosines in the FcR $\gamma$-chain ITAM by Src family tyrosine kinases, followed by binding and activation of the tandem $\mathrm{SH} 2$ domain-containing Syk tyrosine kinase which regulates a complex downstream signaling pathway that involves the adapter proteins LAT, Gads and SLP-76, the Tec family tyrosine kinases Btk and Tec, the small G protein Rac1, the GTP exchange factors Vav1 and Vav3, the ubiquitinating protein, c-Cbl, PI 3-kinase $\alpha$ and $\beta$ isoforms and PLC $\gamma 2 .^{32}$

Quek et al. have shown that collagen and a collagen-related peptide (CRP), which binds to GPVI but does not bind to the integrin $\alpha 2 \beta 1$, induced Btk tyrosine phosphorylation in platelets. Aggregation, dense granule secretion and calcium mobilization were shown to be significantly diminished but not completely abolished in platelets from XLA patients in response to collagen and CRP. These effects were associated with a reduction in tyrosine phosphorylation of PLC $\gamma 2$. In contrast, aggregation and secretion stimulated by thrombin in Btk-deficient platelets were not significantly altered. These findings demonstrate that Btk is important for collagen signaling via GPVI, but is not essential for thrombin-mediated platelet activation. ${ }^{33}$ We show in a separate review of non-receptor tyrosine kinases the evidence of platelet dysfunction and bleeding risk with Btk inhibitors.

\section{CLEC-2}

C-type lectin-like receptor-2 (CLEC-2) is an endogenous receptor of podoplanin on human platelets. Similar to GpVI, CLEC-2 mediates powerful platelet activation through $\mathrm{Src}$ and Syk kinases, but regulates Syk through a novel dimerization mechanism via a single YxxL motif known as a hemITAM. This again leads to a complex downstream signaling pathway that involves the adapter proteins LAT, Gads and SLP-76, the Tec family tyrosine kinases Btk and Tec, the small G protein Rac1, the GTP exchange factors Vav1 and Vav3, the ubiquitinating protein, c-Cbl, PI 3-kinase $\alpha$ and $\beta$ isoforms and PLC $\gamma 2$. CLEC is expressed at high levels in several tissues and the mucin-type sialoglycoprotein podoplanin (aggrus) is involved in platelet aggregation and tumor metastasis. ${ }^{32}$ Kato et al. clarified the pathophysiological interaction between podoplanin and CLEC-2 in vitro and in vivo using several deletion mutants of CLEC-2 expressed as Fc chimeras. ${ }^{34}$ There is evidence that podolanin/CLEC -2 inhibitors might have a useful immunotherapeutic role in different cancers; however, no clinical trial data are yet available.

\section{Non-tyrosine Kinase Receptors}

Integrins: Integrins are heterodimers, all consisting of $\alpha$ and $\beta$ subunits, and play an essential role in adhesion to the extracellular 
matrix and cellular signaling. They are many and those expressed on platelets mainly include $\boldsymbol{\alpha} 2 \boldsymbol{\beta} 1$ and $\boldsymbol{\alpha} 2 \boldsymbol{\beta} 3$ plus $\boldsymbol{\alpha} 5 \boldsymbol{\beta} 1, \boldsymbol{\alpha} 6 \boldsymbol{\beta} 1$, and $\boldsymbol{\alpha} v \boldsymbol{\beta} 3$. GPIa/IIa $(\boldsymbol{\alpha} 2 \boldsymbol{\beta} 1)$ was the first collagen receptor to be identified on platelets, mainly type I under static and flow conditions. A specific amino acid sequence in collagen used in laboratory studies, GFOGER ( $\mathrm{O}=$ hydroxyproline), promotes stable binding to the I-domain of $\alpha 2 \beta 1$ integrin. Integrin activation is induced by several other platelet agonists, including ADP and thrombin. ${ }^{35}$ Activation of adherent platelets stimulates tyrosine phosphorylation of many of the proteins in the GPVI-FcR $\gamma$-chain cascade, including Src, Syk, SLP76 , and PLC $\gamma 2$, as well as plasma membrane calcium ATPase and focal adhesion kinase FAK. ${ }^{36}$ The role of these integrins is thought to be complimentary to GPVI, and its inhibition or deficiency leads to only minor bleeding.

GPIIb/IIIa or Integrin $\boldsymbol{\alpha} 2 \boldsymbol{\beta} 3$ is highly expressed on platelet surface and it plays significant role in platelet aggregation among other players. Its affinity to fibrinogen is highly increased after initiation and extension phases, related to cystoskeletal changes via $\mathrm{Ca} 2+-d e p e n d e n t$ activation of PKC and PI3K. Fibrongen binding to $\alpha 2 \beta 3$ leads to outside-in signalling through Src and Syk protein tyrosine kinases. Role of other integrins $(\boldsymbol{\alpha} 5 \boldsymbol{\beta} 1, \boldsymbol{\alpha} 6 \boldsymbol{\beta} 1$, and $\boldsymbol{\alpha} v \boldsymbol{\beta} 3)$ in human platelet function is not yet fully studied. Mutations in the genes encoding for these integrins or their blockage with different medications may lead to increased risk of bleeding, e.g, $\boldsymbol{\alpha} 2 \boldsymbol{\beta} 3$ mutations causing Glanzmann's thrombasthenia).

Leucine-rich repeated (LRR) receptors: These include glycoprotein $\mathrm{Ib} / \mathrm{IX} / \mathrm{V}$ and Toll-like receptors (TLRs). GP Ib/IX/V complex is the major platelet receptor mediating interaction with VWF, which ultimately leads to activation of integrin $\boldsymbol{\alpha} 2 \boldsymbol{\beta} 3$. The cytoplasmic part of GP Ib $\alpha$ associates with certain TKs such as PI3K, FAK, and Srcrelated tyrosine kinases (Src, Syk, Fyn and Lyn). GP Ib $\alpha$ normally engages with immobilized VWF and triggers signals through these kinases, leading to transient cytoplasmic $\mathrm{Ca} 2+$ elevations, and protein phosphorylation (PLC $\gamma 2$, ERK-1/2, Syk). These interactions induce TxA2 synthesis and ADP release, leading to activation of $\boldsymbol{\alpha} 2 \boldsymbol{\beta} 3$. GP Ib $\alpha$ also facilitates thrombin's proteolytic action over protease-activated receptors or PARs thus acting as a co-factor Bernard-Soulier syndrome is a rare bleeding disorder characterized by thrombocytopenia and giant platelets. This syndrome's origins relate to a genetic deficiency or dysfunction of platelet $\mathrm{GPIb} / \mathrm{V} /$ IX. Autoantibodies against $\mathrm{Ib} / \mathrm{IX}$ may be present in immune thrombocytopenic purpura, characterized by low platelets and higher risk of bleeding. ${ }^{37}$ As VWF primarily coats exposed vessels with high blood flow, the interaction of this receptor with VWF becomes more important in high shear conditions as revealed by numerous studies. Novel antithrombotic agents targeting GP Ib $\alpha$ have strongly inhibited platelet adhesion, aggregation, and thrombus formation in perfusion chambers at high shear conditions and efficiently dissolved preformed thrombi. ${ }^{38}$ No TKIs have been studied in these disease states. TLRs have no known role in hemostasis.

Table 4 Human Epidermal Growth Factor Receptor (EGFR) Inhibitors

\section{G-Protein coupled transmembrane receptors (GPCR)}

GPCRs are a diverse group of transmembrane receptors called seven-transmembrane receptors because they pass through the cell membrane seven times. ${ }^{39}$ They respond to extracellular signals mediated by a huge diversity of agonists via a mechanism of G-protein coupling. Protease-activated receptors (PARs 1 and 4), purinergic $\mathrm{ADP}$ receptors ( $\mathrm{P} 2 \mathrm{Y} 1$ and $\mathrm{P} 2 \mathrm{Y} 12)$, and thromboxane TxA2 receptors (TP $\alpha$ and TP $\beta$ ) are expressed on human platelets and belong to this family. PAR1 and PAR 4, signal via the G-proteins G12/13 $\alpha$ and $\mathrm{Gq} \alpha$, which evoke the majority of functional platelet responses. P2Y1 signals through Gq $\alpha$, while P2Y12 signals through Gi and PI3K $\beta$ subsequently. It is noteworthy that epinephrine signals in a similar way to ADP-P2Y12. PGI2 signals through Gs. Thrombin receptors only indirectly signal via Gia, i.e. through ADP secretion and autocrine effects. G13 associate with Rho and Rho Kinase and lead to increased cytosolic $\mathrm{Ca} 2+$, while Gq $\alpha$ associates with PLC- $\beta 2$ and MLC downstream. Gi links to PI3K $\beta$, leading to increased cytosolic $\mathrm{Ca} 2+$ levels, and negatively regulates adenylyl cyclase activity. ${ }^{40}$

\section{Her or egfr family kinase inhibitors}

Her (Human Epidermal Growth Factor Receptor) or EGFR Family is composed of 4 transmembranous receptor tyrosine kinases: EGFR (Erb1 or Her1), ERB2 (Her2), ERB 3(Her3) and ERB 4(Her4). Binding of specific ligands to EGFR receptors promotes dimerization and auto phosphorylation of tyrosine residues on the receptors and this activates transduction pathways downstream of EGFR. The Ras/Raf mitogen-activated protein kinase pathway and the phosphoinositol 3-kinase (PI3k)/Akt pathway are two major signaling routes for the HER family. The members of this family are not known to be expressed on human platelets; nevertheless, here we review effect on platelets by different approved EGFR TK inhibitors.

We examined evidence of bleeding or platelet dysfunction attributed to 6 approved EGFR inhibitors from different clinical trials. More than 2,000 patients have been treated with erlotinib in 3 phase III trials, and none of them demonstrated any evidence of platelet dysfunction. ${ }^{41-43}$ On the other hand, two other phase III trials showed 1-2 \% ${ }^{44}$ and $4 \%{ }^{45}$ risk of grade 1-2 thrombocytopenia. This treatment already approved for lung cancer treatment has not reported any evidence of bleeding among all trials (Table 4). Similarly, patients receiving gefitinib had no increased reports of bleeding, although some studies have shown an increased risk of grade 1-2 thrombocytopenia in up to $12 \%{ }^{46}$. Lapatinib is another EGFR inhibitor mainly used in Her2 positive breast cancer. No trial has demonstrated any risk of bleeding or thrombocytopenia associated with lapatanib use. On the other hand, studies of afatinib have shown an increased risk of bleeding, primarily epistaxis up in up to $52 \%$ of treated patients in one study ${ }^{47}$ Other studies have also shown afatinib to increase the risk of epistaxis, as well as thrombocytopenia. Two phase II studies of vandatanib have demonstrated no increased risk of bleeding or thrombocytopenia; however, the total number of patients treated on these studies was only. ${ }^{49}$

\begin{tabular}{llllll}
\hline Drugs & $\begin{array}{l}\text { Reference (Author, } \\
\text { Phase) }\end{array}$ & N & Treatment Dose & Type of Malignancy & Bleeding Complications \\
\hline Erlotinib & $\begin{array}{l}\text { Ciuleanu T et al. }{ }^{41} \\
\text { (Phase III) }\end{array}$ & 424 & $150 \mathrm{mg}$ PO QD ( $\mathrm{n}=203)$ & $\begin{array}{l}\text { Second line treatment of advanced } \\
\text { NSCLC with poor prognosis }\end{array}$ & None reported \\
& $\begin{array}{l}\text { Shepherd FA et } \\
\text { al. }{ }^{42}\end{array}$ & 731 & $\begin{array}{l}150 \mathrm{mg} \text { PO QD } \\
(\mathrm{n}=488)\end{array}$ & $\begin{array}{l}\text { Second line treatment of stage } \\
\text { IIIB/IV NSCLC }\end{array}$ & None reported \\
\hline
\end{tabular}


Table continued...

\begin{tabular}{|c|c|c|c|c|c|}
\hline Drugs & $\begin{array}{l}\text { Reference (Author, } \\
\text { Phase) }\end{array}$ & $\mathbf{N}$ & Treatment Dose & Type of Malignancy & Bleeding Complications \\
\hline & (phase III) & & & & \\
\hline & Cappuzzo F et & 889 & 150 mg PO QD & $\begin{array}{l}\text { Maintenance therapy in } \\
\text { unresectable NSCLC with non- } \\
\text { progressive disease following } \\
\text { first-line platinum-doublet } \\
\text { chemotherapy }\end{array}$ & None reported \\
\hline & (phase III) & & & & \\
\hline & $\begin{array}{l}\text { Rosell R et al. }{ }^{44} \\
\text { (phase III) }\end{array}$ & 174 & 150 mg PO QD $(n=86)$ & $\begin{array}{l}\text { Advanced (stage IIIB/IV) EGFR- } \\
\text { mutation positive NSCLC }\end{array}$ & $\begin{array}{l}\text { Thrombocytopenia: I\% } \\
\text { (grade I-2) }\end{array}$ \\
\hline & $\begin{array}{l}\text { Zhou C et al. }{ }^{45} \\
\text { (phase III) }\end{array}$ & 165 & I50 mg PO QD $(n=83)$ & $\begin{array}{l}\text { Advanced (stage IIIB/IV) EGFR- } \\
\text { mutation positive NSCLC }\end{array}$ & $\begin{array}{l}\text { Thrombocytopenia: } 4 \% \\
\text { (grade I-2) }\end{array}$ \\
\hline \multirow[t]{6}{*}{ Gefitinib } & $\begin{array}{l}\text { Douillard J et al. }{ }^{49} \\
\text { (phase IV, } \\
\text { single arm) }\end{array}$ & 106 & $250 \mathrm{mg}$ PO QD & $\begin{array}{l}\text { Caucasian, stage IIIA-B/IV, EGFR } \\
\text { mutation positive NSCLC }\end{array}$ & None reported \\
\hline & Mok et al. ${ }^{50}$ & 1217 & 250 mg PO QD (n =609) & $\begin{array}{l}\text { Previously untreated, East Asians } \\
\text { with advanced pulmonary } \\
\text { adenocarcinoma and who were } \\
\text { nonsmokers or former light } \\
\text { smokers }\end{array}$ & None reported \\
\hline & (phase III) & & & & \\
\hline & $\begin{array}{l}\text { Maemondo et al. }{ }^{51} \\
\text { (phase III) }\end{array}$ & 230 & 250 mg PO QD (n=115) & $\begin{array}{l}\text { Metastatic, NSCLC, EGFR positive; } \\
\text { previously untreated }\end{array}$ & $\begin{array}{l}\text { Thrombocytopenia: } 7 \% \\
\text { (grade I) }\end{array}$ \\
\hline & Mitsudomi et al. ${ }^{46}$ & 177 & 250 mg PO QD (n = 88) & $\begin{array}{l}\text { Newly diagnosed chemotherapy } \\
\text { naïve stage IIIB/IV NSCLC or } \\
\text { postoperative recurrent with } \\
\text { EGFR mutation }\end{array}$ & $\begin{array}{l}\text { Thrombocytopenia: } 12 \% \\
\text { (grade I-2) }\end{array}$ \\
\hline & (phase III) & & & & \\
\hline \multirow[t]{10}{*}{ Lapatinib } & Blackwell KL et & 296 & 1500 mg PO QD (n = & $\begin{array}{l}\text { Metastatic disease that progressed } \\
\text { on the most recent treatment } \\
\text { regimen, which must be } \\
\text { trastutuzumab containing; ErbB-2 } \\
\text { positive }\end{array}$ & None reported \\
\hline & al. $^{52}$ & & 148) & & \\
\hline & (phase III) & & & & \\
\hline & Burris HA et al. ${ }^{53}$ & 67 & 500 - 1600 mg PO QD & $\begin{array}{l}\text { Advanced-stage refractory solid } \\
\text { tumors with ErBI-expressing and/ } \\
\text { or ErbB2-overexpressing }\end{array}$ & None reported \\
\hline & (phase I) & & & & \\
\hline & $\begin{array}{l}\text { Burris HA et al. }{ }^{54} \\
\text { (phase I) }\end{array}$ & 81 & $\begin{array}{l}\text { I } 75 \text { to } 1800 \mathrm{mg} \text { PO QD } \\
\text { or } 500-900 \mathrm{mg} \text { PO BID }\end{array}$ & Solid tumors & None reported \\
\hline & Chu QS et al. ${ }^{55}$ & 39 & $1250-1500 \mathrm{mg} P O \mathrm{QD}$ & $\begin{array}{l}\text { Advanced breast cancer with } \\
\text { immunohistochemically detectable } \\
\text { estrogen or progesterone } \\
\text { receptors or othjoer cancers that } \\
\text { were eligible }\end{array}$ & None reported \\
\hline & (phase I) & & & & \\
\hline & $\begin{array}{l}\text { Johnston S et al. }{ }^{56} \\
\text { (phase III) }\end{array}$ & 1286 & $\begin{array}{l}\text { I500 mg PO QD (n } \\
=642)\end{array}$ & $\begin{array}{l}\text { Postmenopausal women with HR- } \\
\text { positive metastatic breast cancer }\end{array}$ & None reported \\
\hline & Eskens FALM et al. ${ }^{47}$ & 38 & $10-100 \mathrm{mg} P O Q D$ & Variety of solid tumor malignancies & $\begin{array}{l}\text { Self-limiting epistaxis } \\
\text { without changes in } \\
\text { coagulation }\end{array}$ \\
\hline
\end{tabular}


Table continued...

\begin{tabular}{|c|c|c|c|c|c|}
\hline Drugs & $\begin{array}{l}\text { Reference (Author, } \\
\text { Phase) }\end{array}$ & $\mathbf{N}$ & Treatment Dose & Type of Malignancy & Bleeding Complications \\
\hline & (phase I) & & & & $\begin{array}{l}\text { parameters: } 52.6 \% \text { - dose } \\
\text { level not reported }\end{array}$ \\
\hline & & & & & $\begin{array}{l}\text { Thrombocytopenia: } 5.3 \% \\
\text { (grade I) - dose level not } \\
\text { reported }\end{array}$ \\
\hline & & & & & $\begin{array}{l}\text { Epistaxis: I6.7\% Grade } \\
\text { I:3.3\% (40 mg PO QD) }\end{array}$ \\
\hline \multirow[t]{15}{*}{ Afatinib } & Gordon et al. ${ }^{57}$ & 30 & $10-60 \mathrm{mg}$ PO QD & Variety of solid tumor malignancies & $\begin{array}{l}\text { Grade }>2: 6.6 \%(40 \mathrm{mg} \\
\text { PO QD) Grade I: } 6.6 \%(60 \\
\text { mg PO QD) }\end{array}$ \\
\hline & (phase I) & & & & \\
\hline & Marshall et al..$^{58}$ & 43 & $10-65 \mathrm{mg}$ PO QD & Variety of solid tumor malignancies & $\begin{array}{l}\text { Epistaxis: } 23 \%(4.7 \% \text { at } 20 \\
\mathrm{mg}, 16.3 \% \text { at } 55 \mathrm{mg} \text { and } \\
2.3 \% \text { at } 65 \mathrm{mg})\end{array}$ \\
\hline & (phase I) & & & & \\
\hline & Miller VA et al. ${ }^{59}$ & 585 & 50 mg PO QD & $\begin{array}{l}\text { Advanced, metastatic (stage IIIB/IV) } \\
\text { NSCLC after failure of erlotinib, } \\
\text { gefitinib, or both, and one or two } \\
\text { lines of chemotherapy }\end{array}$ & $\begin{array}{l}\text { Epistaxis: I } 8 \% \text { (grade I: } \\
\text { I } 7 \% \text {, grade } 2: 1 \% \text { ) }\end{array}$ \\
\hline & (phase $2 b / 3$ ) & & $(n=390)$ & & \\
\hline & Yang JC et al. ${ }^{31}$ & 129 & 40 - 50 mg PO QD & $\begin{array}{l}\text { Lung adenocarcinoma with EGFR } \\
\text { positive mutation within exons } \\
|8-2| \text { of the EGFR receptor }\end{array}$ & Afatinib $40 \mathrm{mg}$ \\
\hline & (phase II) [LUX Lung 2] & & & & $\begin{array}{l}\text { Epistaxis: } 25 \% \text { (grade I: } \\
24 \% \text {, grade } 2: 1 \% \text { ) }\end{array}$ \\
\hline & & & & & $\begin{array}{l}\text { Afatinib } 50 \text { mg Epistaxis: } \\
30 \% \text { (grade I) }\end{array}$ \\
\hline & $\begin{array}{l}\text { Yang JC et al. }{ }^{60} \\
\text { (phase III) [LUX Lung 3] }\end{array}$ & 345 & $\begin{array}{l}40 \mathrm{mg} P O \mathrm{QD} \\
(\mathrm{n}=230)\end{array}$ & $\begin{array}{l}\text { Stage IIIB/IV lung adenocarcinoma } \\
\text { with EGFR positive mutation }\end{array}$ & $\begin{array}{l}\text { Epistaxis: I3. I\% (Grade } \\
\text { I-2) }\end{array}$ \\
\hline & Katakami et al. ${ }^{61}$ & 62 & 50 mg PO QD & $\begin{array}{l}\text { Stage IIIB/IV lung adenocarcinoma } \\
\text { who progressed }>\text { I } 2 \text { weeks after } \\
\text { prior erolotinib and/or gefitinib }\end{array}$ & Epistaxis: grade I-2: $25.6 \%$ \\
\hline & (phase II) [LUX Lung 4] & & & & \\
\hline & Wells SA et al. ${ }^{62}$ & 30 & 300 mg PO QD & $\begin{array}{l}\text { Unresectable locally advanced or } \\
\text { metastatic hereditary medullary } \\
\text { thyroid carcinoma }\end{array}$ & None reported \\
\hline & (phase II) & & & & \\
\hline & $\begin{array}{l}\text { Robinson BG et al. }{ }^{63} \\
\text { (phase II) }\end{array}$ & 19 & 100 mg PO QD & $\begin{array}{l}\text { Unresectable, measurable, locally } \\
\text { advanced or metastatic hereditary } \\
\text { medullary thyroid carcinoma }\end{array}$ & None reported \\
\hline
\end{tabular}

The mechanism by which EGFR inhibitors could cause thrombocytopenia or bleeding is not well defined. These small molecule TKIs are often not $100 \%$ specific, and different other targets are concentration dependent. ${ }^{7}$. Some TKIs are expected to inhibit other essential kinases involved in platelet signaling as bruton tyrosine kinase, or blood vessel formation as VEGFR inhibitors which might disrupt blood vessel anatomy. In this mini-review of EGFR inhibitors, we highlighted the risk of bleeding with afatinib. Afatinib is not known to inhibit other TKs. It is a pan Her inhibitor (HER3, EGFR, HER2, and HER4) ${ }^{48}$ Hence there is no clear explanation of its association with its observed bleeding tendency or thrombocytopenia.

\section{Vascular endothelial growth factor inhibitors}

In a similar fashion to EGFRs, VEGFRs are not expressed on human platelet surfaces. There are different usages and approvals of VEGFR inhibitors in human cancer. As a class of drugs they have several side effect profiles in common. This "class" side effect profile includes hypertension, thromboembolic events, bleeding, and proteinuria. ${ }^{64}$ One reason why bleeding might occur relates to VEGFR inhibitors' impairment of normal interaction between platelets and endothelial cells through their association with decreased production of nitric oxide and prostaglandin I2. An increased bleeding tendency is further increased by interruption of angiogenesis, and loss of vascular integrity. ${ }^{64,65}$ Bleeding complications, gastrointestinal perforations and disturbed wound and ulcer healing are all explained by same concept. VEGF is known to induce tissue factor (TF) expression and its inhibition is thought to be another mechanism by which bleeding is enhanced. ${ }^{66,67}$ The mechanism by which thrombocytopenia might occur is not yet known.

In Table 5, we review different clinical trials that investigated 6 VEGFR inhibitors and report their risk of bleeding or thrombocytopenia. While some drugs had no reported risk of bleeding, others clearly showed increased risk mainly of mucosal type of 
bleeding. In addition, deep site or tumor related bleeding and intestinal perforation have been reported with these agents. Axitinib is a VEGFR inhibitor approved for use in metastatic renal cell carcinoma (RCC) as some other VEGR inhibitors. It also inhibits platelet derived growth receptor (PDGFR) and c-KIT at higher concentrations. In two phase III and one phase II studies, axitinib caused bleeding ranging from grades 1 to 3 . Bleeding was mostly mucosal in the form of epistaxis, rectal bleeding, and hematuria, but cerebral bleeding has also been reported to a lesser degree. Thrombocytopenia was also noted in the range of 15 to $19.6 \%$. More importantly, one patient died because

Table 5 Vascular Endothelial Growth Factor Receptor (VEGFR) Inhibitors. of gastrointestinal bleeding after receiving axitinib. ${ }^{68}$ In a similar fashion, such bleeding events, and thrombocytopenia have been seen with sunitinib, sorafenib, regorafenib, and pazopanib. Contrary to findings in trials utilizing these drugs, two clinical trials (Phase I and II) including 246 patients and examining cabozatinib, another agent in this class, reported no bleeding or thrombocytopenia. ${ }^{69,70}$ From a mechanistic point of view, sunitinib also inhibits c-KIT, sorafenib inhibits PDGFR and Raf family kinases, pazopanib inhibits c-KIT, PDGFR and FGFR, while cabozatinib inhibits c-Met.

\begin{tabular}{|c|c|c|c|c|c|}
\hline Drugs & $\begin{array}{l}\text { Reference } \\
\text { (author, phase) }\end{array}$ & $\mathbf{N}$ & Treatment dose & Type of malignancy & Bleeding Complications \\
\hline \multirow[t]{7}{*}{ Axitinib } & Rini et al. ${ }^{68}$ & 723 & 5 mg PO BID* & $\begin{array}{l}\text { Advanced renal cell carcinoma } \\
\text { (RCC) }\end{array}$ & $\begin{array}{l}\text { Thrombocytopenia: I5\% (mostly } \\
\text { grade I-2; grade } 3 / 4 \text { : less than I \%).' } \\
\text { patient with death from gastrointestinal } \\
\text { bleed }\end{array}$ \\
\hline & (phase III) & & $(n=36 I)$ & & \\
\hline & Rini Bl et al..$^{71}$ & 62 & $2-10 \mathrm{mg}$ PO BID & $\begin{array}{l}\text { Metastatic renal cell carcinoma } \\
\text { refractory to prior therapies } \\
\text { that included, but not limited to } \\
\text { sorafenib }\end{array}$ & $\begin{array}{l}\text { Epistaxis: } 16 \% \text { (grade I-2) } \\
\text { Thrombocytopenia: } 19.6 \% \text { (grade } \\
\text { I-2) }\end{array}$ \\
\hline & (phase II) & & & & $\begin{array}{l}\text { Cerebral hemorrhage: } 3.2 \% \text { (grade } \\
3-4 \text { ) }\end{array}$ \\
\hline & Rixe $\mathrm{O}$ et al. ${ }^{72}$ & 52 & $\begin{array}{l}\text { Median dose range } 3.9- \\
11.7 \mathrm{mg} \text { PO QD }\end{array}$ & $\begin{array}{l}\text { Metastatic renal cell carcinoma, } \\
\text { patients failed prior cytokine- } \\
\text { based therapies }\end{array}$ & $\begin{array}{l}\text { Epistaxis: } 10 \% \text { (grade I-2) Hematuria: } \\
5.8 \% \text { (I.9\% grade } 3 \text { ) }\end{array}$ \\
\hline & (phase II) & & & & $\begin{array}{l}\text { Rectal hemorrhage: } 3.8 \% \\
\text { Gastrointestinal }\end{array}$ \\
\hline & & & & & hemorrhage: $1.9 \%$ \\
\hline \multirow[t]{12}{*}{ Sunitinib } & Demetri GD et al. ${ }^{73}$ & 312 & 50 mg PO QD & $\begin{array}{l}\text { Advanced gastrointestinal stromal } \\
\text { tumor, resistant to or intolerant or } \\
\text { previous treatment with imatinib }\end{array}$ & Epistaxis: 7\% (grade I-2) \\
\hline & (phase III) & & $(n=207)$ & & Thrombocytopenia: \\
\hline & & & & & Grade I-2: $36 \%$ \\
\hline & & & & & Grade 3: $4 \%$ \\
\hline & & & & & Grade 4: $1 \%$ \\
\hline & Motzer RJ et al. ${ }^{74}$ & 750 & $50 \mathrm{mg}$ PO QD & $\begin{array}{l}\text { Treatment-naïve metastatic renal } \\
\text { cell carcinoma with a clear cell } \\
\text { component }\end{array}$ & Epistaxis: I8\% (grade I-2), \\
\hline & (phase III) & & $(n=375)$ & & I\% (grade 3) Thrombocytopenia: \\
\hline & & & & & Grade I-2:59\% \\
\hline & & & & & Grade 3: 8\% \\
\hline & & & & & Grade 4: I\% \\
\hline & George $\mathrm{S}$ et al. ${ }^{75}$ & 53 & 37.5 mg PO QD & $\begin{array}{l}\text { Advanced nongastrointestinal } \\
\text { stromal tumor sarcomas }\end{array}$ & $\begin{array}{l}\text { Lower gastrointestinal bleed: } 2 \% \\
\text { (grade 3) Thrombocytopenia: Grade } \\
\text { I-2: } 25 \%\end{array}$ \\
\hline & (phase II) & & & & Grade 3: $8 \%$ \\
\hline \multirow[t]{5}{*}{ Sorafenib } & LLovet JM et & 602 & 400 mg PO BID $(n=299)$ & $\begin{array}{l}\text { Previously untreated advanced } \\
\text { hepatocellular carcinoma }\end{array}$ & $\begin{array}{l}\text { Bleeding: } 7 \% \text { (grade I-2: } 6 \% \text {, grade } \\
3: 1 \% \text { ) }\end{array}$ \\
\hline & al. $^{76}$ & & & & Serious hemorrhagic events: $9 \%$ \\
\hline & (phase III) & & & & $\begin{array}{l}\text { Variceal bleeding: } 2 \% \\
\text { Thrombocytopenia: } 4 \% \text { (grade } 3-4 \text { ) }\end{array}$ \\
\hline & Escudier et al. ${ }^{77}$ & 901 & 400 mg PO BID & $\begin{array}{l}\text { Unresectable and/or metastatic } \\
\text { renal cell carcinoma who had } \\
\text { undergone one prior systemic } \\
\text { therapy }\end{array}$ & None reported \\
\hline & (phase III) & & $(n=45 I)$ & & \\
\hline
\end{tabular}


Table continued...

\begin{tabular}{|c|c|c|c|c|c|}
\hline Drugs & $\begin{array}{l}\text { Reference } \\
\text { (author, phase) }\end{array}$ & $\mathbf{N}$ & Treatment dose & Type of malignancy & Bleeding Complications \\
\hline & Brose MS et al. $^{78}$ & 417 & 400 mg PO BID & $\begin{array}{l}\text { Radioactive iodine-refractory } \\
\text { locally advanced or metastatic } \\
\text { differentiated thyroid cancer that } \\
\text { had progressed within the past I4 } \\
\text { months }\end{array}$ & None reported \\
\hline & (phase III) & & $(n=207)$ & & \\
\hline \multirow[t]{4}{*}{ Regorafenib } & Demetri GD et al..$^{79}$ & 199 & 160 mg PO QD & $\begin{array}{l}\text { Metastatic or unresectable } \\
\text { gastrointestinal stromal tumor, } \\
\text { with failure of at least previous } \\
\text { imatinib and sunitinib }\end{array}$ & None reported \\
\hline & (phase III) & & $(n=133)$ & & \\
\hline & Grothey A et al. ${ }^{80}$ & 760 & 160 mg PO QD & $\begin{array}{l}\text { Metastatic colorectal cancer and } \\
\text { progression during or within } 3 \\
\text { months after the last standard } \\
\text { therapy }\end{array}$ & $\begin{array}{l}\text { Nose bleed: } 7 \% \text { (grade I-2) } \\
\text { Thrombocytopenia: I3\% (mostly } \\
\text { grade I-2, grade 3:3\%, }\end{array}$ \\
\hline & (phase III) & & $(n=500)$ & & grade $4:<1 \%)$ \\
\hline \multirow[t]{17}{*}{ Pazopanib } & $\begin{array}{l}\text { Vanc Der GraafWT } \\
\text { et al. }{ }^{81}\end{array}$ & 372 & 800 mg PO QD & $\begin{array}{l}\text { Angiogenesis inhibitor naïve, } \\
\text { metastatic soft-tissue sarcoma, } \\
\text { progressing despite standard } \\
\text { chemotherapy }\end{array}$ & None reported \\
\hline & (phase III) & & $(n=246)$ & & \\
\hline & $\begin{array}{l}\text { Sternberg } \mathrm{CN} \text { et } \\
\text { al. }^{82}\end{array}$ & 400 & 800 mg PO QD & $\begin{array}{l}\text { Treatment-naïv and cytokine- } \\
\text { pretreated patients with advanced } \\
\text { renal cell carcinoma }\end{array}$ & None reported \\
\hline & (phase III) & & $(n=290)$ & & \\
\hline & Motzer RJ et al. ${ }^{83}$ & $\begin{array}{l}111 \\
0\end{array}$ & 800 mg PO QD & $\begin{array}{l}\text { Clear-cell, metastatic renal-cell } \\
\text { carcinoma }\end{array}$ & Thrombocytopenia:All grades: $38 \%$ \\
\hline & (phase III) & & $(n=557)$ & & Grade 3:5\% \\
\hline & & & & & Epistaxis: \\
\hline & & & & & All grades: $9 \%$ \\
\hline & & & & & Grade $3:<1 \%$ \\
\hline & Hutson TE et al. ${ }^{84}$ & 225 & 800 mg PO QD & Metastatic renal cell carcinoma & Thrombocytopenia:Any grade: $26 \%$ \\
\hline & (phase II) & & & & Grade $3:<1 \%$ \\
\hline & & & & & Grade $4: 2 \%$ \\
\hline & Bible KC et al. ${ }^{85}$ & 39 & 800 mg PO QD & $\begin{array}{l}\text { Metastatic, rapidly progressive, } \\
\text { radioiodine-refractory } \\
\text { differentiated thyroid cancer }\end{array}$ & Thrombocytopenia: Grade I:28\% \\
\hline & (phase II) & & & & $\begin{array}{l}2 \text { patients with self-limiting bleeding } \\
\text { events }\end{array}$ \\
\hline & & & & & $\begin{array}{l}\text { Epistaxis: } 15.4 \% \text { (grade I) Oral } \\
\text { hemorrhage: } 5.1 \% \text { (grade I) }\end{array}$ \\
\hline & & & & & Petechia: $2.6 \%$ \\
\hline & & & & & $\begin{array}{l}\text { Lower gastrointestinal hemorrhage: } \\
7.7 \%\end{array}$ \\
\hline \multirow[t]{4}{*}{ Cabozanitinib } & $\begin{array}{l}\text { Smith DC et al. }{ }^{69} \\
\text { (phase II) }\end{array}$ & $|7|$ & 100 mg PO QD & $\begin{array}{l}\text { Castration-resistant prostate } \\
\text { cancer }\end{array}$ & None reported \\
\hline & Kurzrock $R$ et al. ${ }^{70}$ & 85 & Nine dose levels; & $\begin{array}{l}\text { Solid tumors or lymphomas that } \\
\text { were metastatic or unresectable } \\
\text { who were no longer responding to } \\
\text { conventional therapies or }\end{array}$ & None reported \\
\hline & (phase I) & & MTD I75 mg PO QD & \multicolumn{2}{|c|}{ who had disease for which no standard therapy exists } \\
\hline & & & & \multicolumn{2}{|c|}{ (37 patients with medullary thyroid cancer) } \\
\hline
\end{tabular}

*Axitinib dose increases to $7 \mathrm{mg}$ and then to $10 \mathrm{mg}$, twice daily, were allowed for those patients without hypertension or adverse reactions above grade 2 .

Citation: Sater HA, Gandhi AS, Dainer P, et al. Receptor tyrosine kinases in human platelets: A review of expression, function and inhibition in relation to the risk of bleeding or thrombocytopenia from phase I through phase III trials.J Cancer Prev Curr Res. 2017;8(6):368-379. DOI: 10.15406/jcpcr.2017.08.00298 


\section{Conclusion}

The essence of this review was to shed the light on true risk of bleeding reported in clinical trials of receptor tyrosine kinase receptors. Insulin-like growth factor-1 (IGF-1) receptor antibodies are primarily the only inhibitors of RTKs, expressed on human platelet surface, with clinical significance. Phase I-III trials of these agents show no evidence of bleeding, but we note that thrombocytopenia is more likely to occur with IGF-1R antibodies than other forms of IGR1 receptor TKIs. Among all EGFR inhibitors, only afatinib showed a true risk of bleeding going up to $52.6 \%$. Most of these bleeding episode are mucosal and particularly epistaxis. In addition, VEGFR inhibitors tended to have bleeding risk of less than $10 \%$ but they were more serious and were associated with thrombocytopenia. More dedicated randomized controlled trials are of need to better assess the actual incidence in existing and newly emerging TKIs.

\section{Authors' contributions}

HS is the first author who oversaw all major components of this review. HS reviewed the literature and wrote the manuscript. JP and AG assisted drafting part of the review as well. AG prepared 2 tables. PD reviewed and adjusted the draft for finalization. All authors read and approved the final draft.

\section{Acknowledgments}

Not applicable.

\section{Conflicts of interest}

None.

\section{References}

1. Hubbard SR, Till JH. Protein tyrosine kinase structure and function Annual review of biochemistry. 2000;69(1):373-398.

2. Robinson DR, Wu Y-M, Lin S-F. The protein tyrosine kinase family of the human genome. Oncogene. 2000;19(49):5548-5557.

3. Lemmon MA, Schlessinger J. Cell signaling by receptor tyrosine kinases. Cell. 2010;141(7):1117-1134.

4. Schlessinger J. Cell signaling by receptor tyrosine kinases. Cell. 2000;103(2):211-225.

5. Paul MK, Mukhopadhyay AK. Tyrosine kinase-role and significance in cancer. Int J Med Sci. 2004;1(2):101-115.

6. Arora A, Scholar EM. Role of tyrosine kinase inhibitors in cancer therapy. Journal of Pharmacology and Experimental Therapeutics. 2005;15(3):971-979.

7. Fabian MA, Biggs WH 3rd, Treiber DK, et al. A small molecule-kinase interaction map for clinical kinase inhibitors. Nature biotechnology. 2005;23(3):329-336.

8. Roskoski R. USFDA approved protein kinase inhibitors compiled by Robert Roskoski. 2015.

9. Rivera J, Lozano ML, Navarro-Núñez L, et al. Platelet receptors and signaling in the dynamics of thrombus formation. Haematologica. 2009;94(5):700-711.

10. Swieringa F, Kuijpers MJ, Heemskerk JW, et al. Targeting platelet receptor function in thrombus formation: The risk of bleeding. Blood reviews. 2014;28(1):9-21.

11. Hers I. Insulin-like growth factor-1 potentiates platelet activation via the IRS/PI3K $\alpha$ pathway. Blood. 2007;110(13):4243-4252.
12. Stolla MC, Li D, Lu L, et al. Enhanced platelet activity and thrombosis in a murine model of type I diabetes are partially insulin-like growth factor 1-dependent and phosphoinositide 3-kinase-dependent. Journal of Thrombosis and Haemostasis. 2013;11(5):919-929.

13. Kim S, Garcia A, Jackson SP, et al. Insulin-like growth factor-1 regulates platelet activation through PI3-Ka isoform. Blood. 2007;110(13):42064213

14. Weroha SJ, Haluska P. IGF-1 receptor inhibitors in clinical trialsearly lessons. Journal of mammary gland biology and neoplasia. 2008;13(4):471-483.

15. Tolcher AW, Sarantopoulos J, Patnaik A, et al. Phase I, pharmacokinetic, and pharmacodynamic study of AMG 479, a fully human monoclonal antibody to insulin-like growth factor receptor 1. Journal of Clinical Oncology. 2009;27(34):5800-5807.

16. Tap WD, Demetri G, Barnette P, et al. Phase II study of Ganitumab, a fully human anti-type-1 insulin-like growth factor receptor antibody, in patients with metastatic ewing family tumors or desmoplastic small round cell tumors. J Clin Oncol. 2012;30(15):1849-1856.

17. Schwartz GK, Dickson MA, LoRusso PM, et al. Preclinical and firstin-human phase I studies of KW-2450, an oral tyrosine kinase inhibitor with insulin-like growth factor receptor-1/insulin receptor selectivity. Cancer Sci. 2016;107(4):499-506.

18. Desai J, Solomon B, Davis I, et al. Phase I dose-escalation study of daily BMS-754807, an oral, dual IGF-1R/insulin receptor (IR) inhibitor in subjects with solid tumors. Journal of Clinical Oncology. 2010;28(15):3104-3104.

19. Haluska P, Dhar A, Hou X, et al. Phase II trial of the dual IGF-1R/IR inhibitor BMS-754807 with or without letrozole in aromatase inhibitorresistant breast cancer. Journal of Clinical Oncology. 2011;29(15).

20. Friedlander TW, Weinberg VK, Huang Y, et al. A phase II study of insulin-like growth factor receptor inhibition with nordihydroguaiaretic acid in men with non-metastatic hormone-sensitive prostate cancer. Oncol Rep. 2012;27(1):3-9.

21. Smith DC, Britten C, Clary DO, et al. A phase I study of XL228, a potent IGF1R/AURORA/SRC inhibitor, in patients with solid tumors or hematologic malignancies. Journal of clinical oncology : official journal of the American Society of Clinical Oncology. 2009;27(15):149s.

22. Fassnacht M, Berruti A, Baudin E, et al. Linsitinib (OSI-906) versus placebo for patients with locally advanced or metastatic adrenocortical carcinoma: a double-blind, randomised, phase 3 study. The lancet oncology. 2015;16(4):426-435.

23. Ekman S, Frödin J-E, Harmenberg J, et al. (2011) Clinical phase I study with an insulin-like growth factor-1 receptor inhibitor: experiences in patients with squamous non-small cell lung carcinoma. Acta oncologica. 2011;50(3):441-447.

24. Miyakawa Y, Oda A, Druker B, et al. Recombinant thrombopoietin induces rapid protein tyrosine phosphorylation of Janus kinase 2 and Shc in human blood platelets. Blood. 1995;86(1):23-27.

25. Chen J, Herceg HL, Groopman J, et al. Regulation of platelet activation in vitro by the c-Mpl ligand. Blood. 2011;86(11):4054-4062.

26. Angelillo SA, Burnier L, Flores N, et al. Role of Gas6 receptors in platelet signaling during thrombus stabilization and implications for antithrombotic therapy. Journal of Clinical Investigation. 2005;115(2):237-246.

27. Prévost N, Woulfe DS, Jiang H, et al. Eph kinases and ephrins support thrombus growth and stability by regulating integrin outside-in signaling in platelets. Proceedings of the National Academy of Sciences of the United States of America. 2005;102(28):9820-9825. 
28. Prévost N, Woulfe DS, Tognolini M, et al. Signaling by ephrinB1 and Eph kinases in platelets promotes Rap1 activation, platelet adhesion, and aggregation via effector pathways that do not require phosphorylation of ephrinB1. Blood. 2004;103(4):1348-1355.

29. Funk SD, Orr AW. Ephs and ephrins resurface in inflammation, immunity, and atherosclerosis. Pharmacological Research. 2013;67(1):42-52.

30. Funk SD, Yurdagul A, Albert P, et al. EphA2 activation promotes the endothelial cell inflammatory response a potential role in atherosclerosis. Arteriosclerosis, thrombosis, and vascular biology. 2012;32(3):686695.

31. Yang JC, Shih JY, Su WC, et al. Afatinib for patients with lung adenocarcinoma and epidermal growth factor receptor mutations (LUXLung 2): a phase 2 trial. The lancet oncology. 2012;13(5):539-548.

32. Watson S, Herbert J, Pollitt A. GPVI and CLEC-2 in hemostasis and vascular integrity. Journal of Thrombosis and Haemostasis. 2010;8(7):1456-1467.

33. Quek L, Bolen J, Watson S. A role for Bruton's tyrosine kinase (Btk) in platelet activation by collagen. Current biology. 1998;8(20):1137-1140.

34. Kato Y, Kaneko MK, Kunita A, et al. Molecular analysis of the pathophysiological binding of the platelet aggregation-inducing factor podoplanin to the C-type lectin-like receptor CLEC-2. Cancer sci. 2008;99(1):54-61.

35. Grado DWF, Bennett JS, Snyder SE, et al. Inhibitors of the $\alpha 2 \beta 1 /$ GPIaIIa integrin. Google Patents. 2012.

36. Inoue $\mathrm{O}$, Suzuki IK, Dean WL, et al. Integrin $\alpha 2 \beta 1$ mediates outside-in regulation of platelet spreading on collagen through activation of $\mathrm{Src}$ kinases and PLC $\gamma 2$. J Cell Biol. 2003;160(5):769-780.

37. McMillan R. The pathogenesis of chronic immune thrombocytopenic purpura. Semin Hematol. 2007;44(4 Suppl 5):S3-S11.

38. Lei X, Reheman A, Hou Y, et al. Anfibatide, a novel GPIb complex antagonist, inhibits platelet adhesion and thrombus formation in vitro and in vivo in murine models of thrombosis. Thromb Haemost. 2014;111(2):279-289

39. Trzaskowski B, Latek D, Yuan S, et al. Action of molecular switches in GPCRs-theoretical and experimental studies. Curr Med Chem. 2012;19(8):1090-1109.

40. Broos K, Feys HB, De Meyer SF, et al. Platelets at work in primary hemostasis. Blood Rev. 2011;25(4):155-167.

41. Ciuleanu T, Stelmakh L, Cicenas S, et al. Efficacy and safety of erlotinib versus chemotherapy in second-line treatment of patients with advanced, non-small-cell lung cancer with poor prognosis (TITAN): a randomised multicentre, open-label, phase 3 study. Lancet Oncol. 2012;13(3):300-308.

42. Shepherd FA, Rodrigues Pereira J, Ciuleanu T, et al. Erlotinib in previously treated non-small-cell lung cancer. $N$ Engl $\mathrm{J} \mathrm{Med}$. 2005;353(2):123-132.

43. Cappuzzo F, Ciuleanu T, Stelmakh L, et al. Erlotinib as maintenance treatment in advanced non-small-cell lung cancer: a multicentre, randomised, placebo-controlled phase 3 study. Lancet Oncol. 2010;11(6):521-529.

44. Rosell R, Carcereny E, Gervais R, et al. Erlotinib versus standard chemotherapy as first-line treatment for European patients with advanced EGFR mutation-positive non-small-cell lung cancer (EURTAC): a multicentre, open-label, randomised phase 3 trial. Lancet Oncol. 2012;13(3):239-246.

45. Zhou C, Wu YL, Chen G, et al. Erlotinib versus chemotherapy as firstline treatment for patients with advanced EGFR mutation-positive non-small-cell lung cancer (OPTIMAL, CTONG-0802): a multicentre, open-label, randomised, phase 3 study. Lancet Oncol. 2011;12(8):735742.
46. Mitsudomi T, Morita S, Yatabe Y, et al. Gefitinib versus cisplatin plus docetaxel in patients with non-small-cell lung cancer harbouring mutations of the epidermal growth factor receptor (WJTOG3405): an open label, randomised phase 3 trial. Lancet Oncol. 2010;11(2):121128.

47. Eskens F, Mom C, Planting AS, et al. A phase I dose escalation study of BIBW 2992, an irreversible dual inhibitor of epidermal growth factor receptor 1 (EGFR) and 2 (HER2) tyrosine kinase in a 2-week on, 2week off schedule in patients with advanced solid tumours. Br J Cancer. 2008;98(1):80-85.

48. Yonesaka K, Kudo K, Nishida S, et al. The pan-HER family tyrosine kinase inhibitor afatinib overcomes HER3 ligand heregulin-mediated resistance to EGFR inhibitors in non-small cell lung cancer. Oncotarget. 2015;6(32):33602-33611.

49. Douillard J, Ostoros G, Cobo M, et al. First-line gefitinib in Caucasian EGFR mutation-positive NSCLC patients: a phase-IV, open-label, single-arm study. Br J Cancer. 2014;110(1):55-62.

50. Mok TS, Wu YL, Thongprasert S, et al. Gefitinib or carboplatin-paclitaxel in pulmonary adenocarcinoma. $N$ Engl J Med. 2009;361(10):947-957.

51. Maemondo M, Inoue A, Kobayashi K, et al. Gefitinib or chemotherapy for non-small-cell lung cancer with mutated EGFR. $N$ Engl J Med. 2010;362(25):2380-2388.

52. Blackwell KL, Burstein HJ, Storniolo AM, et al. Randomized study of Lapatinib alone or in combination with trastuzumab in women with ErbB2-positive, trastuzumab-refractory metastatic breast cancer. J Clin Oncol. 2010;28(7):1124-1130.

53. Burris HA, Hurwitz HI, Dees EC, et al. Phase I safety, pharmacokinetics, and clinical activity study of lapatinib (GW572016), a reversible dual inhibitor of epidermal growth factor receptor tyrosine kinases, in heavily pretreated patients with metastatic carcinomas. J Clin Oncol. 2005;23(23):5305-5313

54. Burris HA, Taylor CW, Jones SF, et al. A phase I and pharmacokinetic study of oral lapatinib administered once or twice daily in patients with solid malignancies. Clin Cancer Res. 2009;15(21):6702-6708.

55. Chu QS, Cianfrocca ME, Goldstein LJ, et al. A phase I and pharmacokinetic study of lapatinib in combination with letrozole in patients with advanced cancer. Clin Cancer Res. 2008;14(14):4484 4490.

56. Johnston S, Pippen J, Pivot X, et al. Lapatinib combined with letrozole versus letrozole and placebo as first-line therapy for postmenopausal hormone receptor-positive metastatic breast cancer. J Clin Oncol. 2009;27(33):5538-5546.

57. Gordon MS, Mendelson DS, Gross M, et al. A Phase I, open-label, dose-escalation study of continuous once-daily oral treatment with afatinib in patients with advanced solid tumors. Invest New Drugs. 2013;31(2):409-416.

58. Marshall J, Hwang J, Eskens FA, et al. A Phase I, open-label, dose escalation study of afatinib, in a 3-week-on/1-week-off schedule in patients with advanced solid tumors. Invest New Drugs. 2013;31(2):399_ 408

59. Miller VA, Hirsh V, Cadranel J, et al. Afatinib versus placebo for patients with advanced, metastatic non-small-cell lung cancer after failure of erlotinib, gefitinib, or both, and one or two lines of chemotherapy (LUXLung 1): a phase 2b/3 randomised trial. Lancet Oncol. 2012;13(5):528538

60. Yang JC-H, Schuler MH, Yamamoto N, et al. LUX-Lung 3: A randomized, open-label, phase III study of afatinib versus pemetrexed and cisplatin as first-line treatment for patients with advanced adenocarcinoma of the lung harboring EGFR-activating mutations. Paper presented at: ASCO Annual Meeting Proceedings. 2012. 
61. Katakami N, Atagi S, Goto K, et al. LUX-Lung 4: A phase II trial of afatinib in patients with advanced non-small-cell lung cancer who progressed during prior treatment with erlotinib, gefitinib, or both Journal of Clinical Oncology. 2013;31(27):3335-3341.

62. Wells SA, Gosnell JE, Gagel RF, et al. Vandetanib for the treatment of patients with locally advanced or metastatic hereditary medullary thyroid cancer. Journal of Clinical Oncology. 2010;28(5):767-772.

63. Robinson BG, Paz-Ares L, Krebs A, et al. Vandetanib (100 mg) in patients with locally advanced or metastatic hereditary medullary thyroid cancer. The Journal of Clinical Endocrinology \& Metabolism. 2010;95(6):2664-2671.

64. Chen HX, Cleck JN. Adverse effects of anticancer agents that target the VEGF pathway. Nature reviews Clinical oncology. 2009;6(8):465-477.

65. Verheul HM, Pinedo HM. Possible molecular mechanisms involved in the toxicity of angiogenesis inhibition. Nat Rev Cancer. 2007;7(6):475485 .

66. Verheul HM, Jorna AS, Hoekman K, et al. Vascular endothelial growth factor-stimulated endothelial cells promote adhesion and activation of platelets. Blood. 2000;96(13):4216-4221.

67. Zucker S, Mirza H, Conner CE, et al. Vascular endothelial growth factor induces tissue factor and matrix metalloproteinase production in endothelial cells: conversion of prothrombin to thrombin results in progelatinase A activation and cell proliferation. Int $J$ Cancer. 1998;75(5):780-786.

68. Rini BI, Escudier B, Tomczak P, et al. Comparative effectiveness of axitinib versus sorafenib in advanced renal cell carcinoma (AXIS): a randomised phase 3 trial. The Lancet. 2011;378(9807):1931-1939.

69. Smith DC, Smith MR, Sweeney C, et al. Cabozantinib in patients with advanced prostate cancer: results of a phase II randomized discontinuation trial. Journal of clinical oncology. 2013;31(4):412-419.

70. Kurzrock R, Sherman SI, BallDW, etal.Activity of XL184(Cabozantinib), an oral tyrosine kinase inhibitor, in patients with medullary thyroid cancer. Journal of Clinical Oncology. 2011;29(19):2660-2666.

71. Rini BI, Wilding G, Hudes G, et al. Phase II study of axitinib in sorafenib-refractory metastatic renal cell carcinoma. Journal of Clinical Oncology. 2009;27(27):4462-4468.

72. Rixe O, Bukowski RM, Michaelson MD, et al. Axitinib treatment in patients with cytokine-refractory metastatic renal-cell cancer: a phase II study. The lancet oncology. 2007;8(11):975-984

73. Demetri GD, van Oosterom AT, Garrett CR, et al. Efficacy and safety of sunitinib in patients with advanced gastrointestinal stromal tumour after failure of imatinib: a randomised controlled trial. The Lancet. 2006;368(9544):1329-1338.
74. Motzer RJ, Hutson TE, Tomczak $P$, et al Overall survival and updated results for sunitinib compared with interferon alfa in patients with metastatic renal cell carcinoma. Journal of Clinical Oncology. 2009;27(22):3584-3590

75. George S, Merriam P, Maki RG, et al. Multicenter phase II trial of sunitinib in the treatment of nongastrointestinal stromal tumor sarcomas. Journal of Clinical Oncology. 2009;27(19):3154-3160.

76. Llovet JM, Ricci S, Mazzaferro V, et al. Sorafenib in advanced hepatocellular carcinoma. $N$ Engl J Med. 2008;359(4):378-390.

77. Escudier B, Eisen T, Stadler WM, et al. Sorafenib for treatment of renal cell carcinoma: final efficacy and safety results of the phase III treatment approaches in renal cancer global evaluation trial. $J$ Clin Oncol. 2009;27(20):3312-3318.

78. Brose MS, Nutting CM, Jarzab B, et al. Sorafenib in radioactive iodine-refractory, locally advanced or metastatic differentiated thyroid cancer: a randomised, double-blind, phase 3 trial. The Lancet. 2014;384(9940):319-328.

79. Demetri GD, Reichardt P, Kang YK, et al. Efficacy and safety of regorafenib for advanced gastrointestinal stromal tumours after failure of imatinib and sunitinib (GRID): an international, multicentre, randomised, placebo-controlled, phase 3 trial. The Lancet. 2013;381(9863):295-302.

80. Grothey A, Van Cutsem E, Sobrero A, et al. Regorafenib monotherapy for previously treated metastatic colorectal cancer (CORRECT): an international, multicentre, randomised, placebo-controlled, phase 3 trial. The Lancet. 2013;381(9863):303-312.

81. van der Graaf WT, Blay JY, Chawla SP, et al. Pazopanib for metastatic soft-tissue sarcoma (PALETTE): a randomised, double-blind, placebocontrolled phase 3 trial. The Lancet. 2012;379(9829):1879-1886.

82. Sternberg C, Szczylik C, Lee E, et al. A randomized, double-blind phase III study of pazopanib in treatment-naive and cytokine-pretreated patients with advanced renal cell carcinoma (RCC). Journal of Clinical Oncology. 2009;27(15):5021-5021.

83. Motzer RJ, Hutson TE, Cella D, et al. Pazopanib versus sunitinib in metastatic renal-cell carcinoma. New England Journal of Medicine. 2013;369(8):722-731.

84. Hutson TE, Davis ID, Machiels J-PH, et al. Efficacy and safety of pazopanib in patients with metastatic renal cell carcinoma. Journal of Clinical Oncology. 2010;28(3):475-480.

85. Bible KC, Suman VJ, Molina JR, et al. Efficacy of pazopanib in progressive, radioiodine-refractory, metastatic differentiated thyroid cancers: results of a phase 2 consortium study. The lancet oncology. 2010;11(10):962-972. 